\title{
USE OF NATURAL ANTIOXIDANTS FROM LYOPHILIZED WATER EXTRACTS OF BORAGO OFFICINALIS IN DRY FERMENTED SAUSAGES ENRICHED IN $\omega$-3 PUFA
}

Mikel García-Iñiguez de Ciriano, Cecilia García-Herreros, Eduardo Larequi, Idoia Valencia, Diana Ansorena, Iciar Astiasarán*

Department of Nutrition, Food Science, Physiology and Toxicology, Faculty of Pharmacy, University of Navarra, Irunlarrea s/n, 31008-Pamplona, Spain.

*Corresponding author: Tel.: +34 948425600 (extn. 6405); Fax: +34 948425649. E-mail address: iastiasa@unav.es 


\begin{abstract}
An evaluation of the capacity of a lyophilized water extract of borage leaves to delay the lipid oxidation process in dry fermented sausages enriched with $\omega-3$ PUFAs has been performed. 340 ppm of lyophilized extract showed an antioxidant capacity equivalent to $200 \mathrm{ppm}$ of a butylhydroxyanisol (BHA) and butylhydroxytoluene (BHT) mixture. Two batches of dry fermented sausages enriched in $\omega-3$ PUFA were developed. One of them was supplemented with a synthetic antioxidants mixture (200 ppm of BHA + BHT $)$ and the other one with natural antioxidants (340 ppm of lyophilized water extract of borage leaves). Furthermore, a traditional formulation of this type of dry fermented sausage (Control), was also manufactured. The natural extract gave rise to lower amount of volatile compounds (including hexanal), than the mixture of synthetic antioxidants (2202 and 2713 ng dodecane / g dry matter, respectively). TBARS and Cholesterol Oxidation Products (COPs) did not show significant differences between products with different antioxidants. The sensorial analysis showed that lyophilized water extracts of borage leaves did not affect the sensorial properties of the products. From the economical and safety standpoints, the use of a by-product (borage leaves) and water as extracting solvent are valuable alternatives for obtaining natural antioxidants to be added to dry fermented sausages enriched in $\omega-3$ PUFA.
\end{abstract}

\title{
Keywords:
}

$\omega-3$ PUFA, lipid oxidation, linseed oil, COPs, volatile compounds, borage leaves. 


\section{INTRODUCTION}

A number of authors have reported that $\omega$-3 PUFA have a protective effect against coronary heart disease (Colussi et al., 2007), cardiovascular diseases (Ruxton, Reed, Simpson \& Millington, 2004) breast and colon cancer (Rose \& Connolly, 1999), rheumatoid arthritis (Cleland, James \& Proudman, 2003), fibrosis cystic (Beckles Wilson, Elliott \& Everal, 2003). Furthermore, a high $\omega-6 / \omega-3$ PUFA ratio is a well known great risk factor of atherosclerosis and coronary heart disease (Okuyama, Fujii \& Ikemoto, 2000).

The modification of meat products by enrichment in $\omega-3$ PUFA could improve the nutritional quality of these products contributing to increase the intake of those fatty acids, considered low in Western diets. However, a relatively high unsaturated fat content in dry fermented sausages can increase lipid oxidation susceptibility, which is one of the major causes of quality deterioration of processed meat, imposing adverse effects on flavor, color as well as on nutritional value (Byrne, Bredie, Bak, Bertelsen, Martens, \& Martens, 2001). In order to prevent it, antioxidants should be incorporated into the formulation, as their inclusion in foods is one of the most efficient ways for delaying lipid oxidation (Alamed, McClements \& Decker, 2006). This fact was stated by Ansorena and Astiasarán (2004a) in a previous work dealing with $\omega-3$ PUFA enriched dry fermented meat products that incorporated a mixture of BHA+BHT.

In the last years, for human health and consumers perception's reasons, alternative natural antioxidants are being under research (Naczk \& Shahidi, 2006). Furthermore, natural antioxidant compounds provide protection against harmful free radicals, which can be formed in the organism and have been strongly associated with reduced risk of chronic diseases such as cardiovascular disease, cancer, diabetes, 
Alzheimer diseases and cataracts (Gungaard, Nielsen, Olsen \& Soresen, 2003; Gosslau \& Chen, 2004).

Different vegetable extracts, including by-products, rich in polyphenols have been reported as potential antioxidants in different foods such as edible oils, fish and meat products, showing in some cases better results than synthetic antioxidants (Tang, Kerry, Sheehan, Buckley \& Morrissey, 2001; Tang, Kerry, Sheehan \& Buckley, 2002; Sebranek, Sewalt, Robbins \& Houser, 2005; Vuorela, Salminen, Makela, Kivikari, Karonen \& Heinonen, 2005; Haak, Raes, Van Dyck \& De Smet, 2008; Valencia, O’Grady, Ansorena, Astiasarán \& Kerry, 2008; Calvo, García \& Selgas, 2008; Hernández-Hernández, Ponce-Alquicira, Jaramillo-Flores, \& Guerrero Legarreta, 2009). Tabata, Katsube, Tsuma, Ohta, Imawaka, and Utsumi (2008), evaluating the antioxidant properties of water extracts from Mallotus japonicus leaves, used for drugs and folk medicines, concluded that they could be an excellent natural source of antioxidant materials.

Borage (Borago officinalis L.) has been defined as a "power food" of the future because of its content on unsaturated fatty acids (Río-Celestino, Font \& Haro-Bailón, 2008). Moreover, different works have remarked the antioxidant activity of borage extracts (obtained from defatted seeds), especially related to their content in phenolic compounds (Wettasinghe \& Shahidi, 1999; Wettasinghe, Shahidi, Amarowicz \& AbouZaid, 2001). As borage leaves ( $>60 \%$ of the plant matter) are considered by some food processing industries as a by-product, it could be worthwhile to use this material as a cheap source of antioxidant properties in food systems.

The aim of this study was to evaluate the capacity of lyophilized water extracts of borage leaves for protecting dry fermented sausages enriched in $\omega-3$ PUFA from linseed oil from oxidative deterioration. To achieve this objective, the antioxidant 
capacity of the obtained lyophilized extract was firstly determined, and then, a study comparing its efficacy to that of artificial antioxidants in the meat product was carried out.

\section{MATERIALS AND METHODS}

\section{Vegetal material preparation}

$10 \mathrm{~kg}$ of borage (Borago officinalis L.) were purchased fresh from a local supermarket. The plant leaves were separated, cleaned, washed and homogenized. Aqueous extracts were prepared as follows: $100 \mathrm{ml}$ of distilled water, preheated at $96^{\circ}$ $\mathrm{C}$, were added to $100 \mathrm{~g}$ of leaves. The mixture was subjected to sonication during 30 minutes at room temperature, and filtered through a metallic mesh. Extraction process was repeated with another $100 \mathrm{ml}$ of preheated distilled water, and both extracts were joined and completed with distilled water to a final volume of $250 \mathrm{ml}$. Extracts were filtered through Albet 400 filters to remove any kind of solid particle.

Extracts were lyophilized with a freeze-dryer-cryodo (Telstar, Barcelona, Spain), previous freezing at $-80^{\circ} \mathrm{C}$ in a MDF-V5386S Ultra-Low-Temperature Freezer (Sanyo Electric Co., Ltd., Japan). $1.5 \mathrm{~g}$ of lyophilized were obtained from $100 \mathrm{~g}$ of fresh borage leaves. The lyophilized material was subsequently used for the evaluation of the antioxidant capacity and for application as ingredient in the dry fermented sausage formulation. Water extraction was performed in triplicate.

\section{Determination of antioxidant capacity}

Determination of Total phenolic content (TPC)

TPC was determined spectrophotometrically following the Folin-Ciocalteu colorimetric method (Singleton \& Rossi, 1965). Dilutions of lyophilized water extract of borage leaves ranging from 4.25 to $0.02 \mathrm{mg} / \mathrm{ml}$ were used. $0.1 \mathrm{ml}$ of suitably diluted sample, $7.9 \mathrm{ml}$ of distilled water, $0.5 \mathrm{ml}$ of Folin-Ciocalteu's reagent, and $1.5 \mathrm{ml}$ of $20 \%$ 
sodium carbonate anhydrous solution (added 2 minutes after the Folin-Ciocalteu's reagent) were mixed and the tubes were left at room temperature for 2 hours in the dark. Absorbance was measured at $765 \mathrm{~nm}$ using a Lambda 5-UV-VIS spectrophotometer (Perkin Elmer, Paris, France). The total phenolic content was expressed as mg gallic acid / g lyophilized extract.

\section{DPPH method}

The DPPH assay was performed according to the method of Blois (1958) with some modifications. Briefly, a DPPH solution of approximately $20 \mathrm{mg} / \mathrm{ml}$ was prepared in methanol and diluted to obtain an absorbance of 0.8 at $516 \mathrm{~nm}$ (working solution). $2 \mathrm{ml}$ of diluted lyophilized extract of borage leaves of different concentrations (4.25 - $0.02 \mathrm{mg} / \mathrm{ml}$ ) were allowed to react with $2 \mathrm{ml}$ of DPPH working solution during 30 minutes in the dark, at room temperature. A control sample was prepared with $2 \mathrm{ml}$ of methanol. The final absorbance of the reaction mixture was measured at $516 \mathrm{~nm}$ (Lambda 5 UV-VIS Spectrophotometer, Perkin Elmer, Paris, France). The radical scavenging capacity of each dilution was calculated as percent of inhibition (\% I), calculated according to the formula:

$$
\% \mathrm{I}=\left(\mathrm{Abs}_{\mathrm{control}}-\mathrm{Abs}_{\mathrm{sample}}\right) / \mathrm{Abs} \text { control } * 100
$$

Where $\mathrm{Abs}_{\text {control }}$ was the absorbance of the control after 30 minutes of reaction

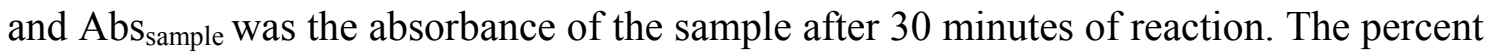
of inhibition was plotted versus the concentration of the extracts. A calibration curve with Trolox $(0.1-2000 \mu \mathrm{g} / \mathrm{ml})$ was used for calculating the antioxidant capacity. Results were finally expressed as mg Trolox / g lyophilized extract of borage leaves. 


\section{ABTS method}

For ABTS assay, the procedure described by Re, Pellegrini, Proteggente, Pannala, Yang and Rice-Evans (1999) with some modifications was used. Briefly, the $\mathrm{ABTS}^{+}$chromogenic radical was generated by a chemical reaction mixing an aqueous solution of ABTS with $\mathrm{K}_{2} \mathrm{~S}_{2} \mathrm{O}_{4}(140 \mathrm{mM})$ to reach a $7 \mathrm{mM}$ final concentration of ABTS. The mixture was kept in the dark for 12-16 hours at room temperature (stock solution). Before use, $1 \mathrm{ml}$ of $\mathrm{ABTS}^{++}$stock solution was diluted with ethanol $50 \%$ to an absorbance of $0.70(+/-0.02)$ at $741 \mathrm{~nm}$ (working solution). $3 \mathrm{ml}$ of $\mathrm{ABTS}^{++}$working solution was allowed to react with $300 \mu$ of suitably diluted water lyophilized water extract of borage leaves $(4.25 \mathrm{mg} / \mathrm{ml}-0.13 \mathrm{mg} / \mathrm{ml}$ ) or control (ethanol - $50 \%$ ) during 6 minutes, and absorbance was measured at $741 \mathrm{~nm}$ (Lambda 5 UV-VIS Spectophotometer, Perkin Elmer, Paris, France). The decrease in absorbance was recorded as percent of inhibition (\% I) and was calculated according to the formula:

$$
\% \mathrm{I}=\left(\mathrm{Abs}_{\mathrm{control}^{-}} \mathrm{Abs}_{\mathrm{sample}}\right) / \mathrm{Abs} \text { control } 100
$$

Where $\mathrm{Abs}_{\text {control }}$ was the absorbance of the control after 6 minutes of reaction and $\mathrm{Abs}_{\text {sample was }}$ the absorbance of the sample after 6 minutes of reaction. The percent of inhibition was plotted versus the concentration of the extracts. A calibration curve with Trolox $(0.1-60 \mu \mathrm{g} / \mathrm{ml})$ was used for calculating the antioxidant capacity. Results were finally expressed as mg Trolox / g lyophilized extract of borage leaves.

\section{Sausage formulation and processing}

Three batches of dry fermented sausages (chorizo de Pamplona), about $8 \mathrm{Kg}$ each, were prepared according to the procedure described by Muguerza, Gimeno, Ansorena, Bloukas, and Astiasarán (2001). The control batch was elaborated using 75\% lean pork meat and $25 \%$ pork back fat. In the modified batches, a substitution of $25 \%$ of 
pork back fat by an emulsion containing linseed oil was carried out. The emulsion was prepared mixing, for two minutes, eight parts of hot water with one part of isolated soy protein and then with ten parts of linseed oil for other three minutes (Hoogenkamp, 1989a,b). The following ingredients per kilogram of meat mixture were added to both formulations: $\mathrm{NaCl} 26 \mathrm{~g}$, red pepper $30 \mathrm{~g}$, dextrin $15 \mathrm{~g}$, lactose $10 \mathrm{~g}$, powdered milk 12 g, dextrose $5 \mathrm{~g}$, sodium ascorbate $0.5 \mathrm{~g}$, sodium caseinate $10 \mathrm{~g}$, garlic $3 \mathrm{~g}$, polyphosphates $2 \mathrm{~g}$, curing agents (a mixture of $\mathrm{NaCl}$, preservatives E-250, E-252 and antioxidant E-331) $3 \mathrm{~g}$, ponceau 4R (E-124) $0.15 \mathrm{~g}$. One of the modified batches 100 $\mathrm{mg} / \mathrm{Kg}$ of butylhydroxytoluene (BHT) and $100 \mathrm{mg} / \mathrm{Kg}$ of butylhydroxyanisole (BHA) were added as synthetic antioxidants, and in the other modified batch $340 \mathrm{ppm}$ of lyophilized water extract of borage leaves were used as a source of natural antioxidants. Sausages were fermented and ripened for 30 days under conditions described by Muguerza et al. (2001) in a drying chamber (STA model W 80XDHG-VEH Noain, Spain). The analysis was carried out at the end of the ripening process.

\section{Chemical analysis.}

The method of Folch, Lees and Stanley (1957) was used for the extraction of lipids. Boron trifluoride / methanol was used for the preparation of fatty acid methyl esters (AOAC, 2002a). Fatty acids were determined in the lipid extract by gas chromatography according to the procedure described by Valencia et al. (2008).

Peroxides were determined according to the AOAC method (AOAC, 2002b). TBA value was determined according to Tarladgis, Watts, Younathan, and Dugan (1960) with modifications by Tarladgis, Pearson and Dugan (1964). Results are shown in mg malonaldehyde / $\mathrm{kg}$ sample (ppm).

Cholesterol content was analyzed by gas chromatography with previous extraction according to Kovacs, Anderson and Ackman (1979). A Perkin-Elmer 
Autosystem XL gas chromatograph equipped with an HP1 column (30 m x $0.25 \mathrm{~mm} \times$ $0.1 \mu \mathrm{m})$ was used. Chromatographic conditions were those described by Conchillo, Ansorena, and Astiasarán (2005).

COP: Extraction of lipids and saponification.

Saponification was made according to the method of Guardiola, Codony, Rafecas and Boatella (1995). Approximately $1 \mathrm{~g}$ of fat was added to a flask containing $10 \mathrm{ml}$ of $1 \mathrm{M} \mathrm{KOH}$ in methanol and $1 \mathrm{ml}$ of $19-H y d r o x y c h o l e s t e r o l$ as internal standard and kept at room temperature during $22 \mathrm{~h}$ to complete the cold saponification. The unsaponificable material was extracted with diethyl ether, washed with water, filtered through anhydrous sodium sulfate, and evaporated till dryness. A purification with silica cartridges and a derivatization to obtain the trimethyl silyl ethers was performed. Oxysterols content was determined by a Hewlett-Packard 6980 GC with 5973 Mass selective Detector. A HP-5MS column (30 m X 250 um X 0.25 um) was used. The chromatographic conditions were those described by Conchillo, Ansorena, and Astiasarán (2005)

\section{Volatile compounds from lipid oxidation}

A Likens-Nickerson extraction using dichloromethane was carried out according to the method described by Ansorena, Zapelena, Astiasarán and Bello (1998). $25 \mathrm{~g}$ of frozen sausage were ground and placed in a $250 \mathrm{ml}$ flask with $100 \mathrm{ml}$ of water. A second flask with $5 \mathrm{ml}$ of dichloromethane and $150 \mu \mathrm{g}$ of dodecane (internal standard) was also attached to a modified Likens-Nickerson apparatus. $5 \mathrm{ml}$ of dichloromethane were also added to fill the apparatus solvent return loop. Both solvent and sample mixture were heated to $70^{\circ} \mathrm{C}$ and boiling temperature, respectively, maintaining these conditions for $2 \mathrm{~h}$. After cooling to ambient temperature, the extract of dichloromethane was collected and dried over anhydrous $\mathrm{Na}_{2} \mathrm{SO}_{4}$. 
Analysis. The volatile compounds were analyzed in a HP 6890 GC system (Hewlett-Packard, Palo Alto, USA) coupled to a 5973 mass selective detector (HewlettPackard). A total of $1 \mu \mathrm{l}$ of the extract was injected into the GC, equipped with a capillary column (30 m X $250 \mu \mathrm{m}$ X $0.25 \mu \mathrm{m}$ nominal HP-5MS). The chromatographic conditions were those described by Ansorena and Astiasarán (2004b).

\section{Sensory evaluation}

Two types of sensorial analysis were carried out at the end of the ripening process. A triangular test was performed to determine the existence of perceptible sensorial differences in appearance, odor and taste between the two batches of linseed oil containing sausages. 9 trained panelists participated in the sessions. Samples were presented sliced, on a white plate, at room temperature. Each panelist was presented with three samples, of which two were identical, and asked to indicate which sample differed from the others. The number of correct responses was determined and data shown in the table corresponded to the mean value obtained for each type of product by 9 members taking into account scores given by all panelists. The statistical analysis of data was done according to the Norma UNE 87-006-92 (1992) (See Data analysis section).

A quantitative descriptive analysis (QDA) was used for evaluating color, typical sausage odor, rancid taste, juiciness, and non-typical taste. Four samples per batch were examined by 10 selected and trained panelists A continue scale between among 1 and 5 was used for evaluation. A value of 1.0 corresponded to the lowest intensity for each parameter and a value of 5.0 to the highest. General acceptability was also evaluated. 


\section{Data Analysis.}

Four samples were analyzed from each type of dry fermented sausage. Each parameter was determined four times in each sample. In tables, means and standard deviations are shown.

A one way Anova test and the Tukey b posteriori test were used to determine significant differences among the different types of sausages for each analyzed parameter. Different letters indicated significant differences among samples at a level of significance of $95 \%(\mathrm{p}<0.05)$. The statistics package chosen for analysis was SPSS version 15.0 (SPSS inc. Chicago, Illinois, USA).

Statistical treatment for the triangular test sensorial analysis was performed using the Norma UNE 87-006-92 (1992). For a 9 members panel, the difference between samples was significant if the number of correct answers was $6(p<0.05), 7$ $(\mathrm{p}<0.01)$ and $8(\mathrm{p}<0.001)$.

\section{RESULTS AND DISCUSSION}

\section{Antioxidant characterization of lyophilized extracts}

The antioxidant capacity of the lyophilized water extract of borage leaves was evaluated by DPPH and ABTS methods. The analysis showed values of $51.0 \mathrm{mg}$ Trolox / $\mathrm{g}$ of lyophilized extract using the DPPH method and $50.5 \mathrm{mg}$ Trolox / $\mathrm{g}$ of lyophilized extract for ABTS assay. Similar values have been found in the edible part of borage for ABTS after extraction with water and acetone from previously boiled samples (Salvatore et al., 2005). Sun, Powers and Tang (2007), analyzing the antioxidant activity in water extracts of asparagus and broccoli, and Ferracane et al. (2008), analyzing water/acetone extract of artichoke, both expressing results in mmol Trolox /g dry 
weight, found also 10-fold lower values for ABTS results compared to the lyophilized water extract of borage leaves extracts analyzed in this work.

The antioxidant activity of plants is, in most of them, significantly related to their phenolic compounds content. Wettasinghe and Shahidi (1999) analyzing the antioxidant and free radical-scavenging properties of the ethanolic extracts of defatted borage seeds concluded that these extracts retarded lipid oxidation due to their content on phenolic compounds. The total phenolic compounds content obtained in the borage extract was $57.7 \mathrm{mg}$ gallic acid / g lyophilized extract, corresponding to approximately $0.9 \mathrm{mg}$ gallic acid / g fresh plant. These values are higher than the phenolic content detected in acetone extracts of other edible plants such as broccoli, spinach or onion (Chu, Sun, Wu, \& Liu, 2002). All these data concerning antioxidant capacity and total phenolic compounds pointed out the important antioxidant potential of the borage leaves.

Once demonstrated the antioxidant potential of this borage by-product, it was assayed to test its capacity to retard the lipid oxidation. In order to use an effective amount of lyophilized extract, the antioxidant activity of a mixture of BHT and BHA at a level of 200 ppm (a usual concentration in foodstuffs) was evaluated by the DPPH method, giving as a result $86.10 \mathrm{mg}$ Trolox /g of antioxidant mixture. Comparing with the results obtained for the lyophilized water extract of borage leaves, it could be concluded that $200 \mathrm{ppm}(\mathrm{BHA}+\mathrm{BHT})$ was equivalent to $340 \mathrm{ppm}$ of lyophilized water extract, so this amount was the addition level used for the experiment.

\section{Dry fermented sausages}

Three types of products were elaborated in a pilot plant: a control batch, with a traditional formulation, and two batches with a partial substitution of pork back fat by linseed oil, each one containing either natural or synthetic antioxidants. The fatty acid 
profile of the three batches at the end of the ripening process is shown in Table 1. The differences between the control and the rest of the products were due to the partial substitution of pork back fat by linseed oil, being very similar to those described by Ansorena and Astiasarán (2004a). The highest difference corresponded to the $\alpha$ linolenic acid, which showed values of $7.6-8 \mathrm{~g} / 100 \mathrm{~g}$ total fatty acids in modified batches, 9-fold the values found for the control. Hoz, D'Arrigo, Cambero and Ordóñez (2004) developing $\omega$-3 fatty acid enriched dry fermented sausages elaborated with back fat and meat from animals fed on diets enriched in linseed oil obtained products with $6 \%$ of $\alpha$-linolenic acid (7-fold the values found for the control). Comparing the two modified products elaborated with different antioxidants, some significant but very slight differences were observed for the 25 fatty acid analyzed: products with lyophilized extract showed higher amounts of oleic, linoleic, EPA and DHA acids and lower amounts of $\alpha$-linolenic acid. These differences, although quantitatively very small, could point out to a higher antioxidant capacity of the lyophilized water extract, preserving the degradation of unsaturated fatty acids.

Tables 2 and 3 show the results obtained for different parameters related to the intensity of lipid oxidation. Peroxides, primary oxidation products, maintained low levels in modified products, both with artificial and natural antioxidants. The amount of secondary oxidation products, measured by TBARS values, also showed lower values in modified products compared to control ones. Ansorena and Astiasarán (2004a) reported, in modified sausages with linseed oil without antioxidant, TBARS values 3-fold higher than those with the BHT and BHA mixture, concluding that some strategy to control the oxidation in these products was needed. Sánchez-Escalante, Djenane, Torrescano, Beltrán and Roncalés (2003) found that extracts from borage seeds showed an antioxidant action in beef patties, maintaining low TBARS values. In that work, no 
significant differences were found between samples with synthetic and natural antioxidants for TBARS.

These results were confirmed by the analysis of volatile compounds, mainly aldehydes, which basically result from the oxidative degradation of different fatty acids. Modified products, especially those added with lyophilized borage extract showed lower values of volatile compounds (2202 and $2713 \mathrm{ng}$ dodecane / g dry matter) than control products (3196 ng dodecane / g dry matter). Hexanal, which is considered a typical oxidation indicator derived from linoleic acid degradation, and in general, a good indicator of the oxidation level (Shahidi \& Pegg, 1994), was significantly lower in the lyophilized extract containing products ( $842 \mathrm{ng}$ dodecane / g dry matter) than in the other two batches (1015 and 1332 ng dodecane / g dry matter for modified and control products respectively), in agreement with the slightly highest amount of linoleic acid showed by those products. Heptanal, octanal and nonanal also showed the lowest values in products with the lyophilized water extract. These results seem to indicate a higher control of the oxidation in the batches with natural antioxidants than in those with the BHA+BHT mixture.

The study of the oxidation process was completed with the analysis of COPs. Many studies have shown that the presence of a higher PUFA content is related to a higher concentration of COPs (Li, Ohshima, Shozen, Ushio \& Koizumi, 1994; Eder, Grunthal, Kluge, Hirche, Spilke \& Brandsch, 2005), observing in some cases a significant correlation between TBARS and the total COPs (Monahan et al., 1992; Conchillo, Ansorena \& Astiasarán, 2003). Six from the seven analyzed COPs were found in every analyzed product. No significant differences were found for any of the COPs among the three types of products, being the total amount of COPs similar for all of them and also similar to those found in Milano type sausages (Zanardi, Dorigoni, 
Badiani \& Chizzolini, 2002). These results gave rise to low percentages of cholesterol oxidation (0.01-0.02\%). It can be concluded that both, synthetic and natural antioxidants, are efficient to inhibit the oxidation of cholesterol in the enriched PUFA products.

Vegetable extracts can include compounds that can give especial flavor to the final products. Two sensory tests were carried out in the study to analyze the potential acceptability of the developed products by consumers. A triangular sensorial test was carried out in this work to know whether the panel members were able to distinguish between the two linseed oil containing products. The results of the test (Table 4) indicated that no significant differences were found between both types of products for odor, taste and general appearance. In $67 \%$ of the cases the panel did not distinguish between samples for taste and odor. When appearance was evaluated, the percentage increased to $78 \%$.

Those results were confirmed by the quantitative-descriptive analysis (Figure 1) in which every product was evaluated individually and certain concrete properties were evaluated (color, typical sausages odor, rancid taste, juiciness, and non-typical taste). The scores obtained for the analyzed parameters by the panelists did not show statistically significant differences, being in all cases acceptable values for this type of sausages. Furthermore, the scores obtained for the general acceptability of the developed products were similar among them. These results pointed out that the differences found in relation to the intensity of lipid oxidation were not detected by means of the sensory analysis. It can be concluded that the assayed modifications did not affect the sensorial characteristics of the products.

In conclusion, the lyophilized water extracts of borage leaves can be used as an efficient natural antioxidants source to control the lipid oxidation process in functional 
dry fermented sausages enriched in $\omega-3$ PUFA. Borage leaves, by-products from vegetable processing industry, constitute a cheap source of antioxidant activity. Moreover, the water extraction did not imply over-cost neither safety problems. 


\section{ACKNOWLEDGEMENTS}

We thank the "Programa Consolider-Ingenio 2010 CARNISENUSA CSD200700016" and the "Proyecto AGL2008-01099/ALI" (Ministerio de Ciencia e Innovación), and the "Plan Investigador de la Universidad de Navarra" (PIUNA) for their contribution to the financial support of this work. We are also grateful to Dr. Mohino (ANVISA). 


\section{REFERENCES}

Alamed, J., McClements, D. J. \& Decker, E. A. (2006). Influence of heat processing and calcium ions on the ability of EDTA to inhibit lipid oxidation in oil-in-water emulsions containing omega-3 fatty acids. Food Chemistry, 95(4), 585-590.

Ansorena, D., Zapelena, M. J., Astiasarán, I. \& Bello, J. (1998). Addition of Palatase M (lipase from Rhizomucor miehei) to dry fermented sausages: Effect over lipolysis and study of the further oxidation process by GC-MS. Journal of Agricultural and Food Chemistry, 46(8), 3244-3248.

Ansorena, D. \& Astiasarán, I. (2004a). The use of linseed oil improves nutritional quality of the lipid fraction of dry-fermented sausages. Food Chemistry, 87(1), 6974.

Ansorena, D. \& Astiasarán, I. (2004b). Effect of storage and packaging on fatty acid composition and oxidation in dry fermented sausages made with added olive oil and antioxidants. Meat Science, 67(2), 237-244.

AOAC. (2002a). Methyl esters of fatty acids in oils and fats. 969.33. In Official Methods of Analysis.(pp. 19-20). Gaithersburg, Maryland: Association of Official Analytical Chemists.

AOAC. (2002b). Determination of peroxide content. 965.33. In Official Method of Analysis.(pp. 12). Gaithersburg, Maryland: Association of Official Analytical Chemists. 
Beckles Wilson, N., Elliott, T. M. \& Everal, M. L. (2003). Omega-3 fatty acids (from fish oils) for cystic fibrosis (cochrane review). In The Cochrane Library. Oxford: Update Software.

Blois, M. S. (1958). Antioxidant determinations by the use of a stable free radical. Nature, 181(4617), 1199-1200.

Byrne, D. V., Bredie, W. L. P., Bak, L. S., Bertelsen, G., Martens, H. \& Martens, M. (2001). Sensory and chemical analysis of cooked porcine meat patties in relation to warmed-over flavour and pre-slaughter stress. Meat Science, 59(3), 229-249.

Calvo, M. M., García, M. L. \& Selgas, M. D. (2008). Dry fermented sausages enriched with lycopene from tomato peel. Meat Science, 80(2), 167-172.

Chu, Y., Sun, J., Wu, X. \& Liu, R. H. (2002). Antioxidant and antiproliferative activities of common vegetables. Journal of Agricultural and Food Chemistry, 50(23), 6910-6916.

Cleland, L. G., James, M. J. \& Proudman, S. M. (2003). The role of fish oils in the treatment of rheumatoid arthritis. Drugs, 63(9), 845-853.

Colussi, G., Catena, C., Baroselli, S., Nadalini, E., Lapenna, R., Chiuch, A. \& Sechi, L. A. (2007). Omega-3 fatty acids: from biochemistry to their clinical use in the prevention of cardiovascular disease. Recent Patents on Cardiovascular Drug Discovery, 2(1), 13.

Conchillo, A., Ansorena, D. \& Astiasarán, I. (2003). Combined effect of cooking (grilling and roasting) and chilling storage (with and without air) on lipid and 
cholesterol oxidation in chicken breast. Journal of Food Protection, 66(5), 840846.

Conchillo, A., Ansorena, D. \& Astiasarán, I. (2005). Intensity of lipid oxidation and formation of cholesterol oxidation products during frozen storage of raw and cooked chicken. Journal of the Science of Food and Agriculture, 85(1), 141.

Eder, K., Grunthal, G., Kluge, H., Hirche, F., Spilke, J. \& Brandsch, C. (2005). Concentrations of cholesterol oxidation products in raw, heat-processed and frozenstored meat of broiler chickens fed diets differing in the type of fat and vitamin $\mathrm{E}$ concentrations. The British Journal of Nutrition, 93(5), 633-643.

Ferracane, R., Pellegrini, N., Visconti, A., Graziani, G., Chiavaro, E., Miglio, C. \& Fogliano, V. (2008). Effects of different cooking methods on antioxidant profile, antioxidant capacity, and physical characteristics of artichoke. Journal of Agricultural and Food Chemistry, 56(18), 8601-8608.

Folch, J., Lees, M. \& Stanley, G. H. S. (1957). A simple method for the isolation and purification of total lipides from animal tissues. The Journal of Biological Chemistry, 226(1), 497-509.

Gosslau, A. \& Chen, K. Y. (2004). Nutraceuticals, apoptosis, and disease prevention. Nutrition, 20(1), 95-102.

Guardiola, F., Codony, R., Rafecas, M. \& Boatella, J. (1995). Comparision of 3 methods for the determination of oxysterols in spray-dried egg. Journal of Chromatography, 705(2), 289-304. 
Gundgaard, J., Nielsen, J. N., Olsen, J. \& Sorensen, J. (2003). Increased intake of fruit and vegetables: estimation of impact in terms of life expectancy and healthcare costs. Public Health Nutrition, 6(1), 25-30.

Haak, L., Raes, K., Van Dyck, S. \& De Smet, S. (2008). Effect of dietary rosemary and $\alpha$-tocopheryl acetate on the oxidative stability of raw and cooked pork following oxidized linseed oil administration. Meat Science, 78(3), 239-247.

Hernández-Hernández, E., Ponce-Alquicira, E., Jaramillo-Flores, M. E. \& Guerrero Legarreta, I. (2009). Antioxidant effect rosemary (Rosmarinus officinalis L.) and oregano (Origanum vulgare L.) extracts on TBARS and colour of model raw pork batters. Meat Science, 81(2), 410-417.

Hoogenkamp, H. W. (1989a). Low-calorie sausages, spreads and mousses. Fleischerei, 40(11; 12), III-IV.

Hoogenkamp, H. W. (1989b). Low-fat and low-cholesterol sausages. Fleischerei, 40(10), III-IV.

Hoz, L., D’Arrigo, M., Cambero, I. \& Ordóñez, J. A. (2004). Development of an n-3 fatty acid and $\alpha$-tocopherol enriched dry fermented sausage. Meat Science, 67(3), 485-495.

Kovacs, M. I. P., Anderson, W. E. \& Ackman, R. G. (1979). Simple method for the determination of cholesterol and some plant sterols in fishery-based food-products. Journal of Food Science, 44(5), 1299-\&. 
Li, N., Ohshima, T., Shozen, K., Ushio, H. \& Koizumi, C. (1994). Effects of the degree of unsaturation of coexisting triacylglycerols on cholesterol oxidation. Journal of the American Oil Chemists' Society, 71(6), 623-627.

Monahan, F. J., Gray, J. I., Booren, A. M., Miller, E. R., Buckley, D. J., Morrissey, P. A. \& Gomaa, E. A. (1992). Influence of dietary treatment on lipid and cholesterol oxidation in pork. Journal of Agricultural and Food Chemistry, 40(8), 1310-1315.

Muguerza, E., Gimeno, O., Ansorena, D., Bloukas, J. G. \& Astiasarán, I. (2001). Effect of replacing pork backfat with pre-emulsified olive oil on lipid fraction and sensory quality of Chorizo de Pamplona — a traditional Spanish fermented sausage. Meat Science, 59(3), 251-258.

Naczk, M. \& Shahidi, F. (2006). Phenolics in cereals, fruits and vegetables: Occurrence, extraction and analysis. Journal of Pharmaceutical and Biomedical Analysis, 41(5), 1523-1542.

Okuyama, H., Fujii, Y. \& Ikemoto, A. (2000). n-6/n-3 ratio of dietary fatty acids rather than hypercholesterolemia as the major risk factor for atherosclerosis and coronary heart disease. Journal of Health Science, 46(3), 157-177.

Re, R., Pellegrini, N., Proteggente, A., Pannala, A., Yang, M. \& Rice-Evans, C. (1999). Antioxidant activity applying an improved ABTS radical cation decolorization assay. Free Radical Biology Medicine, 26(9-10), 1231-1237.

Río-Celestino, M. d., Font, R. \& de Haro-Bailón, A. (2008). Distribution of fatty acids in edible organs and seed fractions of borage (Borago officinalis L.). Journal of the Science of Food and Agriculture, 88(2), 248-255. 
Rose, D. P. \& Connolly, J. M. (1999). Antiangiogenicity of docosahexaenoic acid and its role in the suppression of breast cancer cell growth in nude mice. International Journal of Oncology, 15(5), 1011-1015.

Ruxton, C. H. S., Reed, S. C., Simpson, M. J. A. \& Millington, K. J. (2004). The health benefits of omega-3 polyunsaturated fatty acids: a review of the evidence. Journal of Human Nutrition and Dietetics, 17, 449-459.

Salvatore, S., Pellegrini, N., Brenna, O. V., Del Rio, D., Frasca, G., Brighenti, F. \& Tumino, R. (2005). Antioxidant characterization of some Sicilian edible wild greens. Journal of Agricultural and Food Chemistry, 53(24), 9465-9471.

Sánchez-Escalante, A., Djenane, D., Torrescano, G., Beltrán, J. A. \& Roncalés, P. (2003). Antioxidant action of borage, rosemary, oregano, and ascorbic acid in beef patties packaged in modified atmosphere. Journal of Food Science, 68(1), 339-344.

Sebranek, J. G., Sewalt, V. J. H., Robbins, K. L. \& Houser, T. A. (2005). Comparison of a natural rosemary extract and BHA/BHT for relative antioxidant effectiveness in pork sausage. Meat Science, 69(2), 289-296.

Shahidi, F. \& Pegg, R. B. (1994). Hexanal as an indicator of the flavor deterioration of meat and meat products. ACS Symposium Series, (558), 256-279.

Singleton, V. L. \& Rossi, J. A. (1965). Colorimetry of total phenolics with phosphomolybdic-phosphotungstic acid reagents. American Journal of Enology and Viticulture, 16, 144-158.

Sun, T., Powers, J. R. \& Tang, J. (2007). Evaluation of the antioxidant activity of asparagus, broccoli and their juices. Food Chemistry, 105(1), 101-106. 
Tabata, H., Katsube, T., Tsuma, T., Ohta, Y., Imawaka, N. \& Utsumi, T. (2008). Isolation and evaluation of the radical-scavenging activity of the antioxidants in the leaves of an edible plant, Mallotus japonicus. Food Chemistry, 109(1), 64-71.

Tang, S., Kerry, J. P., Sheehan, D., Buckley, D. J. \& Morrissey, P. A. (2001). Antioxidative effect of added tea catechins on susceptibility of cooked red meat, poultry and fish patties to lipid oxidation. Food Research International, 34(8), 651657.

Tang, S., Kerry, J. P., Sheehan, D. \& Buckley, D. J. (2002). Antioxidative mechanisms of tea catechins in chicken meat systems. Food Chemistry, 76(1), 45-51.

Tarladgis, B. G., Watts, B. M., Younathan, M. T. \& Dugan, L. R., Jr. (1960). A distillation method for the quantitative determination of malonaldehyde in rancid foods. Journal of the American Oil Chemists' Society, 37(1), 44-48.

Tarladgis, B. G., Pearson, A. M. \& Dugan, L. R., Jr. (1964). Chemistry of 2thiobarbituric acid test for determination of oxidative rancidity in foods II. Formation of TBA-malonaldehyde complex without acid-heat treatment. Journal of the Science of Food and Agriculture, 15(9), 602-607.

UNE 87-006-92. (1992). Norma Española. Metodología Prueba Triangular.

Valencia, I., O’Grady, M. N., Ansorena, D., Astiasarán, I. \& Kerry, J. P. (2008). Enhancement of the nutritional status and quality of fresh pork sausages following the addition of linseed oil, fish oil and natural antioxidants. Meat Science, 80(4), 1046-1054. 
Vuorela, S., Salminen, H., Makela, M., Kivikari, R., Karonen, M. \& Heinonen, M. (2005). Effect of Plant Phenolics on Protein and Lipid Oxidation in Cooked Pork Meat Patties. Journal of Agricultural and Food Chemistry, 53(22), 8492-8497.

Wettasinghe, M. \& Shahidi, F. (1999). Antioxidant and free radical-scavenging properties of ethanolic extracts of defatted borage (Borago officinalis L.) seeds. Food Chemistry, 67(4), 399-414.

Wettasinghe, M., Shahidi, F., Amarowicz, R. \& Abou-Zaid, M. M. (2001). Phenolic acids in defatted seeds of borage (Borago officinalis L.). Food Chemistry, 75(1), 49-56.

Zanardi, E., Dorigoni, V., Badiani, A. \& Chizzolini, R. (2002). Lipid and colour stability of Milano-type sausages: effect of packing conditions. Meat Science, 61(1), 7-14. 


\section{FIGURE CAPTIONS}

Figure 1. Sensory scores of a quantitative descriptive analysis for each one of the developed products. 


\section{TABLE CAPTIONS}

Table 1. Content of total fatty acids for the three types of dry fermented sausages (g/100 g fatty acids).

Table 2 Lipid oxidation parameters in control and modified sausages at the end of the ripening period.

Table 3. Cholesterol oxidation products (COPs) and cholesterol content analyzed at the end of the ripening period of the three types of dry fermented sausages.

Table 4. Sensory scores of triangular test for Synthetic antioxidant vs Natural antioxidant batches of linseed containing dry fermented sausages. 


\section{Figure 1.}

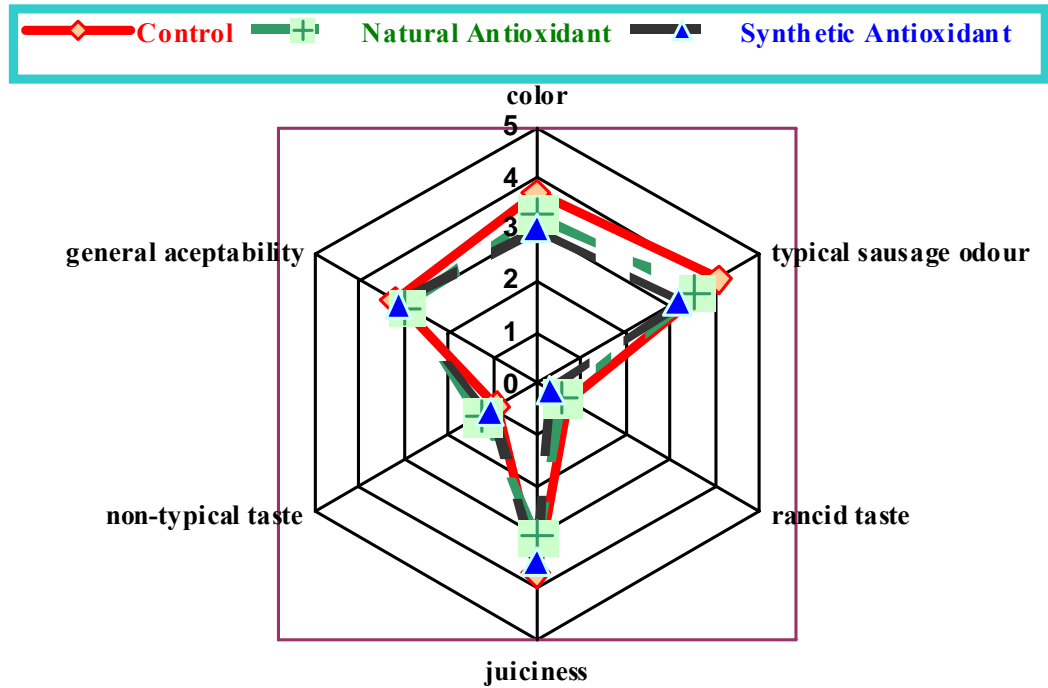


Table 1.

\section{Control Synthetic Antioxidant Natural} Antioxidant

\begin{tabular}{|c|c|c|c|}
\hline Capric C10:0 & $0.15 \pm 0.01 \mathrm{a}$ & $0.15 \pm 0.01 \mathrm{a}$ & $0.14 \pm 0.00 \mathrm{a}$ \\
\hline Lauric C12:0 & $0.10 \pm 0.00 \mathrm{~b}$ & $0.09 \pm 0.00 \mathrm{a}$ & $0.09 \pm 0.00 \mathrm{a}$ \\
\hline Myristic C14:0 & $1.33 \pm 0.01 \mathrm{~b}$ & $1.13 \pm 0.01 \mathrm{a}$ & $1.13 \pm 0.01 \mathrm{a}$ \\
\hline Palmitic C16:0 & $23.84 \pm 0.03 \mathrm{~b}$ & $21.44 \pm 0.02 \mathrm{a}$ & $21.30 \pm 0.06 \mathrm{a}$ \\
\hline t-Palmitoleic C16:1t & $0.34 \pm 0.00 \mathrm{~b}$ & $0.29 \pm 0.01 \mathrm{a}$ & $0.31 \pm 0.00 \mathrm{a}$ \\
\hline Palmitoleic C16:1 & $1.95 \pm 0.09 \mathrm{~b}$ & $1.66 \pm 0.01 \mathrm{a}$ & $1.66 \pm 0.01 \mathrm{a}$ \\
\hline Stearic C18:0 & $13.84 \pm 0.10 b$ & $12.31 \pm 0.08 \mathrm{a}$ & $12.36 \pm 0.00 \mathrm{a}$ \\
\hline Elaidic C18:1t & $0.45 \pm 0.02 \mathrm{~b}$ & $0.40 \pm 0.02 \mathrm{a}$ & $0.42 \pm 0.02 \mathrm{a}$ \\
\hline Oleic C18:1( $\omega-9)$ & $39.69 \pm 0.04 \mathrm{c}$ & $36.67 \pm 0.06 \mathrm{a}$ & $36.84 \pm 0.08 b$ \\
\hline Vaccenic C18:1( $\omega-7)$ & $2.91 \pm 0.00 \mathrm{~b}$ & $2.68 \pm 0.00 \mathrm{a}$ & $2.68 \pm 0.01 \mathrm{a}$ \\
\hline$t$-Linoleic C18:2t & $0.10 \pm 0.01 \mathrm{a}$ & $0.10 \pm 0.01 \mathrm{a}$ & $0.10 \pm 0.00 \mathrm{a}$ \\
\hline$c-t$ linoleic C18:1c.1t & $0.06 \pm 0.01 \mathrm{a}$ & $0.07 \pm 0.00 \mathrm{a}$ & $0.06 \pm 0.00 \mathrm{a}$ \\
\hline$t-c$ linoleic C18:1t.1c & $0.06 \pm 0.00 \mathrm{a}$ & $0.07 \pm 0.00 \mathrm{a}$ & $0.06 \pm 0.00 \mathrm{a}$ \\
\hline Linoleic C18:2( $\omega-6)$ & $12.80 \pm 0.05 \mathrm{a}$ & $13.55 \pm 0.05 \mathrm{~b}$ & $13.81 \pm 0.01 \mathrm{c}$ \\
\hline Arachidic C20:0 & $0.07 \pm 0.01 \mathrm{a}$ & $0.08 \pm 0.01 \mathrm{a}$ & $0.06 \pm 0.01 \mathrm{a}$ \\
\hline$\gamma$-linolenic C18:3 $(\omega-6)$ & $0.03 \pm 0.00 \mathrm{a}$ & $0.03 \pm 0.00 \mathrm{a}$ & $0.03 \pm 0.00 \mathrm{a}$ \\
\hline Eicosenoic C20:1( $\omega-9)$ & $0.84 \pm 0.01 \mathrm{~b}$ & $0.74 \pm 0.01 \mathrm{a}$ & $0.75 \pm 0.00 \mathrm{a}$ \\
\hline$\alpha$-linolenic C18:3( $\omega-3)$ & $0.85 \pm 0.00 \mathrm{a}$ & $7.94 \pm 0.05 \mathrm{c}$ & $7.58 \pm 0.02 b$ \\
\hline Behenic C22:0 & $0.08 \pm 0.00 \mathrm{a}$ & $0.07 \pm 0.01 \mathrm{a}$ & $0.07 \pm 0.00 \mathrm{a}$ \\
\hline Brasidic C20:1t & $0.01 \pm 0.00 \mathrm{a}$ & $0.01 \pm 0.00 \mathrm{a}$ & $0.01 \pm 0.00 \mathrm{a}$ \\
\hline Erucic C22:1 & $0.11 \pm 0.01 \mathrm{a}$ & $0.10 \pm 0.00 \mathrm{a}$ & $0.10 \pm 0.00 \mathrm{a}$ \\
\hline Eicosatrienoic C20:3( $\omega-3)$ & $0.33 \pm 0.00 \mathrm{a}$ & $0.34 \pm 0.04 \mathrm{a}$ & $0.34 \pm 0.03 \mathrm{a}$ \\
\hline 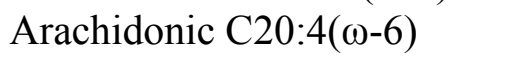 & $0.01 \pm 0.00 \mathrm{a}$ & $0.01 \pm 0.00 \mathrm{a}$ & $0.01 \pm 0.00 \mathrm{a}$ \\
\hline Eicosapentaenoic C22:5( $\omega-6)$ & $0.02 \pm 0.00 \mathrm{a}$ & $0.02 \pm 0.00 \mathrm{a}$ & $0.04 \pm 0.00 \mathrm{~b}$ \\
\hline Docosahexaenoic C22:6( $\omega-3)$ & $0.03 \pm 0.00 \mathrm{a}$ & $0.03 \pm 0.00 \mathrm{a}$ & $0.08 \pm 0.01 \mathrm{~b}$ \\
\hline
\end{tabular}

For each fatty acid, different letters denote significant differences among types of formulations $(\mathrm{p}<0.05)$. Results are expressed as mean \pm standard deviation. 
Table 2.

\begin{tabular}{lccc}
\hline & Control & $\begin{array}{c}\text { Synthetic } \\
\text { Antioxidant }\end{array}$ & $\begin{array}{c}\text { Natural } \\
\text { Antioxidant }\end{array}$ \\
\hline PI & $4.57 \pm 0.25 \mathrm{c}$ & $0.76 \pm 0.20 \mathrm{a}$ & $2.94 \pm 0.60 \mathrm{~b}$ \\
TBARS & $0.32 \pm 0.00 \mathrm{a}$ & $0.29 \pm 0.01 \mathrm{~b}$ & $0.26 \pm 0.01 \mathrm{~b}$ \\
& $1332 \pm 34 \mathrm{c}$ & $1015 \pm 35 \mathrm{~b}$ & $842 \pm 52 \mathrm{a}$ \\
Hexanal & $122 \pm 6 \mathrm{~b}$ & $130 \pm 21 \mathrm{~b}$ & $95 \pm 12 \mathrm{a}$ \\
Heptanal & $\mathrm{nd}$. & $\mathrm{nd}$. & nd. \\
t-2-heptenal & $331 \pm 11 \mathrm{~b}$ & $408 \pm 24 \mathrm{c}$ & $285 \pm 7 \mathrm{a}$ \\
2-penthyl amilofurane & nd. & nd. & nd. \\
t,t-2,4-heptadienal & $286 \pm 4 \mathrm{~b}$ & $269 \pm 17 \mathrm{~b}$ & $215 \pm 15 \mathrm{a}$ \\
Octanal & $1125 \pm 101 \mathrm{~b}$ & $891 \pm 89 \mathrm{a}$ & $764 \pm 37 \mathrm{a}$ \\
Nonanal & nd. & nd. & nd. \\
t,t-2,4-decadienal & nd. & nd. & nd. \\
2,4-decadienal & & &
\end{tabular}

Total Volatile compounds $\quad 3196 \pm 84 \mathrm{c} \quad 2713 \pm 114 \mathrm{~b} \quad 2202 \pm 72 \mathrm{a}$

Peroxides (PI) are expressed in meq $\mathrm{O}_{2} / \mathrm{kg}$ fat, TBARS in $\mathrm{mg} \mathrm{MDA} / \mathrm{kg}$ and the volatile compounds in ng dodecane / $\mathrm{g}$ dry matter.

Results are expressed as mean \pm standard deviation.

For each parameter, different letters denote significant differences among types of formulations $(\mathrm{p}<0.05)$. nd.: non detected. 
Table 3.

\begin{tabular}{lccc}
\hline & Control & $\begin{array}{c}\text { Synthetic } \\
\text { Antioxidant }\end{array}$ & $\begin{array}{c}\text { Natural } \\
\text { Antioxidant }\end{array}$ \\
\hline $7 \alpha$-hydroxicholesterol & $0,10 \pm 0,00 \mathrm{a}$ & $0,08 \pm 0,01 \mathrm{a}$ & $0,11 \pm 0,01 \mathrm{a}$ \\
$7 \beta$-hydroxicholesterol & $0,08 \pm 0,01 \mathrm{a}$ & $0,07 \pm 0,01 \mathrm{a}$ & $0,09 \pm 0,01 \mathrm{a}$ \\
$5,6 \beta$-epoxycholesterol & $0,12 \pm 0,01 \mathrm{a}$ & $0,10 \pm 0,01 \mathrm{a}$ & $0,11 \pm 0,02 \mathrm{a}$ \\
$5,6 \alpha$-epoxycholesterol & $0,15 \pm 0,00 \mathrm{a}$ & $0,15 \pm 0,05 \mathrm{a}$ & $0,15 \pm 0,01 \mathrm{a}$ \\
cholestanotriol & nd. & nd. & nd. \\
25-hydroxicholesterol & nd. & nd. & nd. \\
7-ketocholesterol & $0,11 \pm 0,01 \mathrm{a}$ & $0,10 \pm 0,01 \mathrm{a}$ & $0,12 \pm 0,00 \mathrm{a}$ \\
$\Sigma$ COPs & $0,56 \pm 0,03 \mathrm{a}$ & $0,50 \pm 0,08 \mathrm{a}$ & $0,58 \pm 0,03 \mathrm{a}$ \\
Cholesterol & $103 \pm 0.1 \mathrm{a}$ & $101 \pm 0.2 \mathrm{a}$ & $99 \pm 0.4 \mathrm{a}$ \\
\% Oxidation & $0.02 \mathrm{a}$ & $0.01 \mathrm{a}$ & $0.02 \mathrm{a}$ \\
\hline
\end{tabular}

Cholesterol oxides are expressed in $\mu \mathrm{g} / \mathrm{g}$ fat and the cholesterol content in $\mathrm{mg} / 100 \mathrm{~g}$ product. $\%$ oxidation $=[$ COPs $] \times 100 /[$ Cholesterol $]$.

Results are expressed as mean \pm standard deviation.

For each parameter, different letters denote significant differences among types of formulations $(\mathrm{p}<0.01)$. nd.: non detected. 
Table 4.

\begin{tabular}{lccc}
\hline \multicolumn{4}{c}{ Synthetic Antioxidant vs Natural Antioxidant } \\
\hline & $\begin{array}{c}\text { Appearance } \boldsymbol{n} \\
\text { (\% within group) }\end{array}$ & $\begin{array}{l}\text { Odor } \boldsymbol{n} \\
\text { (\% within group) }\end{array}$ & $\begin{array}{l}\text { Taste } \boldsymbol{n} \\
\text { (\% within group) }\end{array}$ \\
\hline Correct replies & $2(22.2 \%) \mathrm{ns}$ & $3(33.3 \%) \mathrm{ns}$ & $3(33.3 \%) \mathrm{ns}$ \\
Incorrect replies & $7(77.8 \%)$ & $6(66.7 \%)$ & $6(66.7 \%)$ \\
Total & $9(100 \%)$ & $9(100 \%)$ & $9(100 \%)$ \\
\hline
\end{tabular}

For $n=9$, the difference between samples was significant if the number of correct answers was $6(p<0.05), 7(p<0.01)$ and $8(p<0.001)$. ns: not significant. 